Chirurgia (2019) 114: 95-102

No. 1, January - February

Copyright $\odot$ Celsius

http://dx.doi.org/10.21614/chirurgia.114.1.95

\title{
Laparoscopic Repair of Small Ventral Hernias Using the "Ventralex" Hernia Patch"
}

\author{
Alexandru Eugen Nicolau, Raluca Vasile, Carmen Haiducu \\ Department of Surgery, Emergency Clinical Hospital Bucharest, Romania
}

Corresponding author:

Alexandru Eugen Nicolau, MD, PhD

Department of Surgery

Emergency Clinical Hospital

Bucharest, Romania

E-mail: aenicolau@gmail.com

\section{Abbreviations:}

VH - Ventral hernias:

PVH - primary ventral hernias;

$\mathrm{UH}$ - umbilical hernias;

EH - epigastric hernias;

TE - trocar eventrations

ePTFE (expanded polytetra-fluoroethylene

\section{Rezumat \\ Cura laparoscopică a herniilor ventrale mici cu plasă "Ventralex" hernia patch"}

Abordul laparoscopic al defectelor parietale ventrale devine tot mai actual, având în vedere avantajele binecunoscute ale chirurgiei miniminvazive la care se adaugă incidența mai redusă a infectiilor parietale postoperatorii şi a recidivelor comparativ cu abordul deschis cu sau fără plasă. Prezentăm tehnica curei laparoscopice a herniilor ventrale mici (defect $<2 \mathrm{~cm}$ ) utilizând plasa Ventralex, bifațetată, polipropilen şi PTFE, circulară, de $8 \mathrm{~cm}$ în diametru, fixată cu 4 fire de sutură transparietale, după închiderea defectului parietal. Plasa respectivă este concepută pentru chirurgia deschisă, dar se poziționează intraperitoneal. Am folosit tehnica la 28 de pacienți pacienți, 16 femei şi 12 bărbați, cu vârsta medie de 53,3 ani (29-72 ani): 22 hernii ombilicale (HO), 2 hernii epigastrice (HE), o hernie Spiegel stg., o hernie incizională după cura deschisă a unei HO cu plasă Ventralex şi 2 eventații de trocar (ET) după colecistectomie laparoscopică. Durata operației a fost în medie de 52 de min (42-70 $\mathrm{min}$ ), spitalizare postoperatorie 1,8 zile (1-5zile). Avantaje: plasă preformată circular, diametru $8 \mathrm{~cm}$, fixare prin sutură transfascială, laparoscopic se verifică corecta poziționare şi depliere, costuri reduse. Tehnica este uşor de reprodus.

Cuvinte cheie: hernie ventrală mică, laparoscopie, plasă

\section{Abstract}

Laparoscopy of abdominal wall defects becomes more and more actual, considering the well-known advantages of minimally 
invasive surgery, and the reduced incidence of post-operative ventral infections and recurrence rates compared to the the open repair with or without mesh. We hereby present the technique of the laparoscopic repair of small ventral hernias (defect $<2$ centimetres), using the Ventralex mesh, which is bi-faceted, polypropylene and PTFE, circular preformed, it has 8 centimeters in diameter, fixated with 4 transparietal sutures. The mesh is created for open surgery but it is placed in the intraperitoneal cavity. This technique was used for 28 patients, 16 women and 12 men, with an average age of 53,3 years (29-72 years), consisting of: 22 umbilical hernias (UH), 2 epigastric hernias (EH), one left-side Spiegelian hernia, one incisional hernia after an open surgery for an umbilical hernia with a Ventralex mesh, and 2 trocar eventrations (TE) after a laparoscopic cholecystectomy. Mean operating time was 52 minutes (42-70 minutes), post-operative hospital stay of 1,8 days (1-5 days). The main advantages are: circular preformed mesh, diameter of 8 centimeters, transfascial suture fixation, correct mesh placement and unfolding may be verified by laparoscopy, reduced costs. The technique is easy to reproduce.

Key words: small ventral hernia, mesh, laparoscopy

\section{Introduction}

Ventral hernias $(\mathrm{VH})$, or anterior abdominal hernias, are ranked second considering their frequency, following inguinal hernias in adults; and they include primary ventral hernias $(\mathrm{PVH})$, and incisional hernias, which are different at an ethiopathogenical level as well, according to the European Hernia Society classification $(1,2)$. In the USA, VH represent over $32 \%$ of total operated hernias in 2011 and 2012 (3).

After their location, PVH are represented by midline hernias, umbilical hernias (UH), the most frequent type, and epigastric hernias $(\mathrm{EH})$ or white line hernias, and lateral hernias, which are rare, Spiegel hernias, and lumbar hernias (2). Considering their dimensions, VH may be small, when the abdominal wall defect does not exceed 2 centimeters, medium-sized hernias, when the defect is of $2^{-}$ 4 centimeters, and large, of over 4 centimeters in size (2). Small incisional hernias are rare and are recurrences following a surgical approach of PVH, or trocar eventrations (TE), on the insertion site of the trocar, following laparoscopic surgery. For small VH, simple suture is the most used surgical technique, followed by mesh suture, recommended in incisional hernias or in patients with recurrence favorable risk factors $(2,4)$. Usage of mesh in small VH is usually recommended by some authors $(4,5)$. Laparoscopy is more frequently used, as the advantages of minimally invasive surgery are well-known, and as more and more patients request this type of treatment. The laparoscopic approach of $\mathrm{VH}$ is associated with a decrease of post-operative complications, especially complications of the abdominal wall, decrease of hospital stay and recovery time, while the incidence of recurrence is similar or reduced (5-7).

In the following, the laparoscopic approach of small VH repair, using the "Ventralex" Hernia Patch" (Davol Inc., CR Bard Inc., RI, USA), is presented.

\section{Material and Method}

The proposed technique addresses small VH, especially elective surgery for small PVH and ET from the insertion site of trocars after laparoscopic surgery. Laparoscopy was performed on patients with small PVH, most of them UH, but on ET as well, in patients with risk of abdominal wall complications and recurrence, on obese patients, diabetic patients, smokers, athletes and upon specific request of patients, considering the advantages of laparoscopic surgery. In obese patients and patients with small eventrations, laparoscopy is the safest, with an incidence of complications 
sensitively reduced compared to open surgery (6-8). "Ventralex ${ }^{\mathrm{TM}}$ Hernia Patch" has been the instrument of choice in this case as it is circular, with a diameter of 8 centimeters, enough to cover defects of maximum 2 centimeters, and with a smaller cost than other meshes for laparoscopy, bigger in size, and obviously, more expensive. Ventralex ${ }^{\mathrm{TM}}$ is used in open surgery as well, but it is positioned in the intraperitoneal cavity, as in laparoscopic surgery. The mesh is self expandable, with two sides, one parietal,made of polypropylene, and one visceral, made of ePTFE (expanded polytetrafluoroethylene), that comes in contact with the viscera. The patch consists of a polypropylene layer attached to an ePTFE layer incorporating a recoil polyethylene terephthalate (PET) memory ring, which acts like a resort in unfolding and flattens the mesh once it is introduced in the intraperitoneal cavity, and two "straps" that help with its fixation in case of open surgery (Fig. 1) (9).

Contraindications of laparoscopic surgery include patients that do not tolerate general anesthesia or pneumoperitoneum due to severe comorbidities, strangled VH, severe coagulopathies, infections of skin tissue, important ascites (Child C).

\section{Operating Technique}

The intervention is performed under general anesthesia IOT, upon induction a dose of

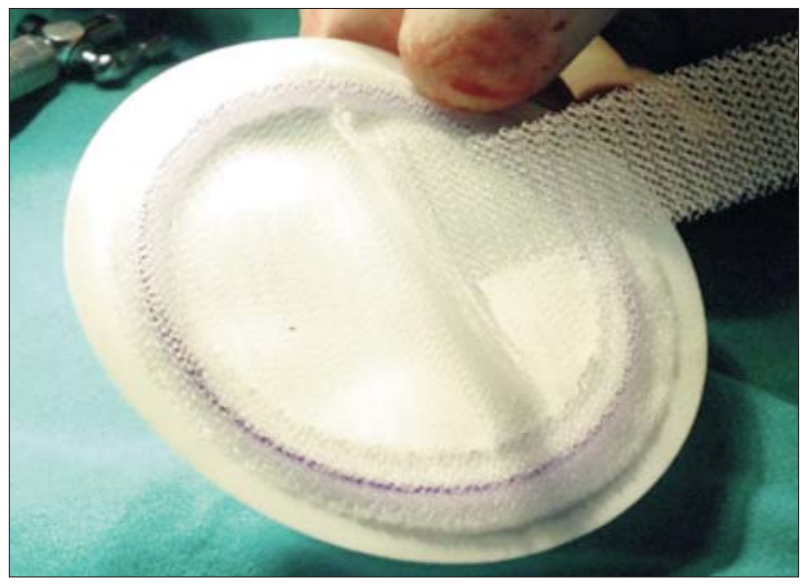

Figure 1. Ventralex mesh antibiotic is administered, for prophylactic purposes. The patient is in dorsal decubitus, with a roll made up of an operating field under the left loin, with the left arm in adduction. After relaxation, the dimension of the defect is marked, and it should not exceed 2 centimeters, and the 4 cardinal points are traced, points that will overlap the mesh at approximately 3 centimeters from the edge of the defect. Disinfection of the skin is done carefully to not erase the markings.

The operating team (surgeon and assistent) are positioned on the left side, the assistent considering the position and the stage, may sit on the right side, or the left side of the surgeon. The video imagistic line is positioned on the right side of the patient. The instruments are the usual ones, plus the transfacial port or one can use a Reverdin port, or Endo Close $^{\mathrm{TM}}$ (Covidien, Boulder, CO, USA) of single use, that passes the intraperitoneal suture and a needle holder, if closing of the abdominal wall defect is performed.

Capnoperitoneum is performed enclosed, with Veress needle placed under the left costal margin on the mid-clavicular line, initial insuflation pressure is $14 \mathrm{mmHg}$, that will be reduced to $12 \mathrm{mmHg}$, after the introduction of the first trocar, and then it will reduced to $8 \mathrm{mmHg}$, when sutures that close the abdominal wall defect close, respective transfacial sutures that fixate the mesh.

The first trocar of 10 millimeters in diameter, "the scope trocar" is introduced facing the umbilicus on the anterior axillary line. The working trocars of $5 \mathrm{~mm}$ in diameter are introduced in plain sight, under the left costal margin on the mid-clavicular line, at about 2-3 $\mathrm{cm}$ median from the antero-posterior iliac spine (Fig. 2). After the introduction of the trocars, the peritoneal cavity is explored. The defect is searched for, viscerolysis is performed if necessary, without electrocoagulation if adhesions are close to the intestine. In small $\mathrm{VH}$, the greater epiploon may be inside the hernia sac and is reduced in the peritoneal cavity. The hernia sac may be partially resected when it can be pulled inside the peritoneal cavity, rarely it may be resected totally by 


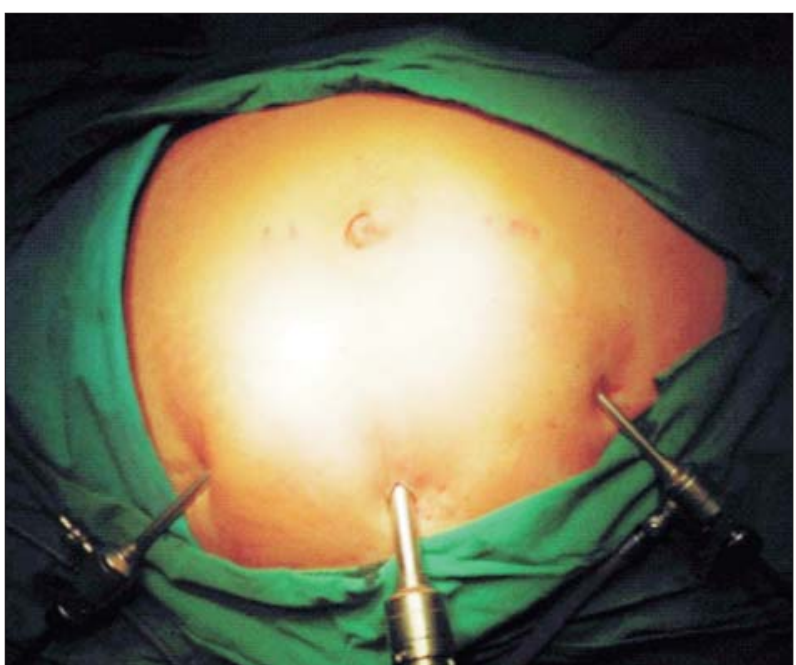

Figure 2. Port placement

exerting pressure and control by introducing the index finger in the parietal defect. When it cannot be excised, a few electrocoagulation points are applied on the surface of the sac. The falciform ligament is excised at minimum $3-4$ $\mathrm{cm}$ to allow the mesh to be in direct contact with the parietal peritoneum.

The repair of the parietal defect could be performedi extraperitoneally, transparietal with prolene suture 2-0 or 0 non-absorbable, suture in shape of an inversed "U" (10). If we decide to close the defect, a $2 \mathrm{~mm}$ skin incision is performed on the outside on the right lateral side of the defect. A prolene 0 or 10 with a big needle $(30-35 \mathrm{~mm}, 3 / 8)$ passes through, from the complete lateral side of the patient into peritoneal cavity, than on the opposite side of the defect, from up to down, with a needle holder (Fig. $3 \mathrm{~A}$ ). The thread is cut and the needle is retrieved through the 10 $\mathrm{mm}$ trocar put in the place of the $5 \mathrm{~mm}$ trocar under the left costal margin. The tissue passer is introduced in the same skin incision in the lateral right side of the defect, and retrieves and exteriorizes the thread, the abdomen defleats to $8 \mathrm{mmHg}$ (Fig. $3 \mathrm{~B}$ ). The threads are tied from the outside and on the subcutaneous supra-aponeurotically. So these are u-reverse stitches.

The mesh is removed from its container, and the straps are sectioned right next to the ring. 12 o'clock or North is marked for orientation by tailoring a $\mathrm{V}$ at the edge of the mesh. Next to the ring, exclusively through the polypropylene mesh, 4 non-absorbable sutures 0 or $2-0$ are passed through (preferably prolene), that correspond to hours $12,9,6,3$ on the clock, that are tied and the ends are left at about $12-15 \mathrm{~cm}$ in length. The mesh is positioned on the skin, centered right next to the defect and in the center of the markings, and with a sharp scalpel (blade 15), next to each knot a miniincision of 2-3 $\mathrm{mm}$ is performed on the skin (hours 12, 9, 6, 3), where the transfacial port is
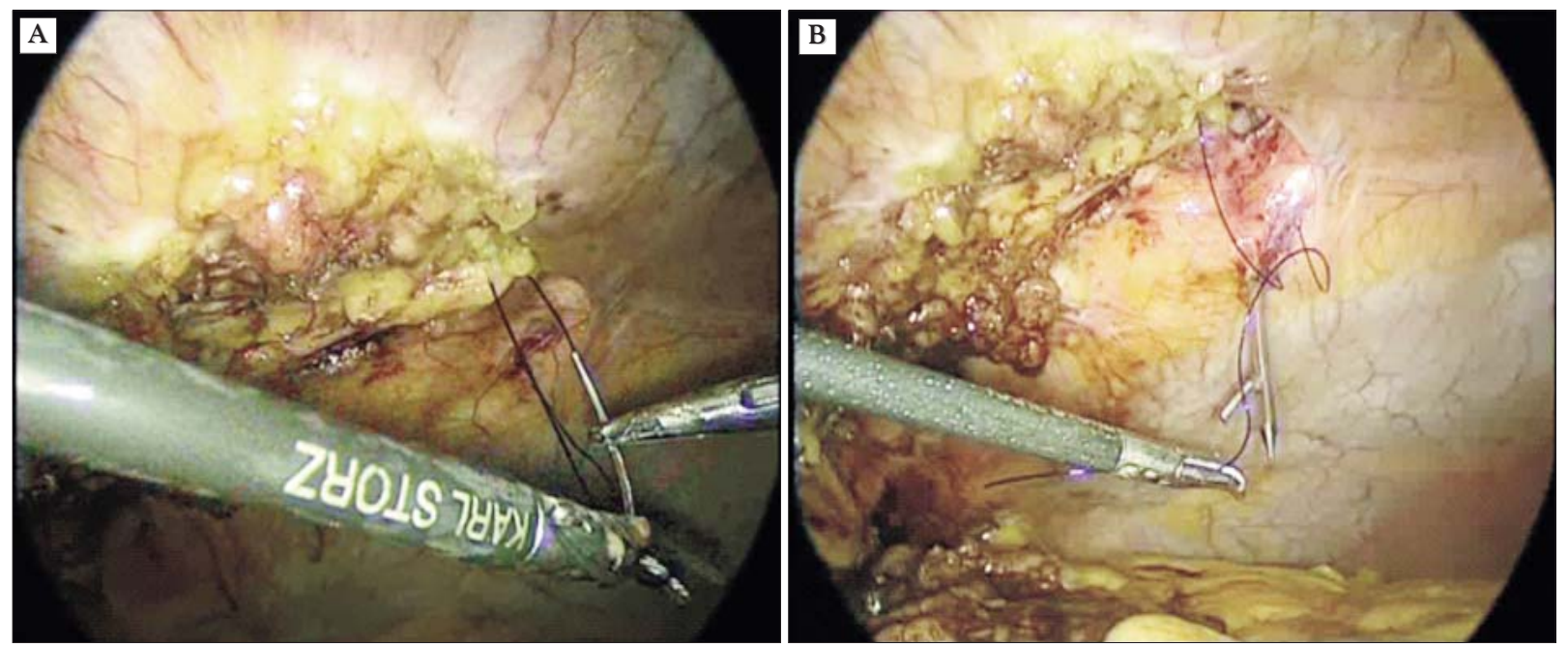

Figure 3. Defect closure with reverse "U" stitch 


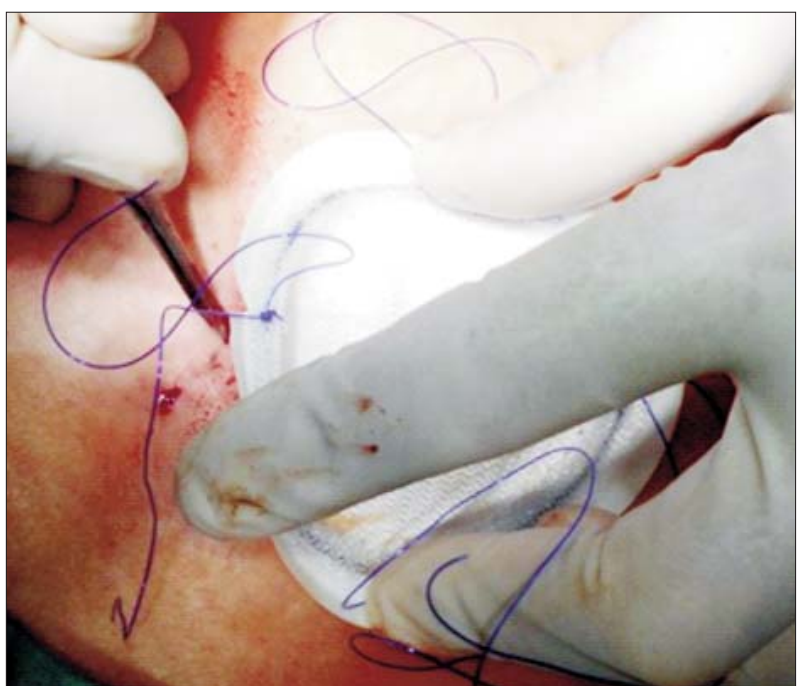

Figure 4. Stitches passed through mesh

introduced to pull out the fixation sutures (Fig. 4). The mesh is damped with physiological serum, the ePTFE part is rolled on the outer side and it is introduced in the peritoneal cavity through the $10 \mathrm{~mm}$ cannula, after removing the valve or by mini-incision after removing the cannula. In the peritoneal cavity, the mesh is held with atraumatic clamps, they are unfolded, and are placed next to the defect with the incision $\mathrm{V}$ cranially. The transfacial port is introduced successively through the 4 mini- $^{-}$ incisions, perpendicular on the abdominal plan and the ends of the fixation sutures applied on the mesh are grabbed and pulled out. Between the exteriorization spots of the pair of sutures there must be a distance of approximately 5 $\mathrm{mm}$ (Fig. 5). The order in which the 4 pairs of sutures are pulled out corresponds to hours 12, $9,6,3$. After the exteriorization, the sutures that form each pair are tied, after the reduction of the intra-abdominal pressure at $8 \mathrm{mmHg}$, and they are cut. The knot is under the skin, suprafascial (Fig. 6). The mesh must be completely unfolded (Fig. 7). The trocar cannulas are removed, the mini-incisions are sutured and a compressive bandage is applied on the defect.

Post-operative, after about 6-8 hours oral rehydration starts, with clear fluids, then progressively, solid food or diet food is introduced, as indicated. Active mobilization is performed

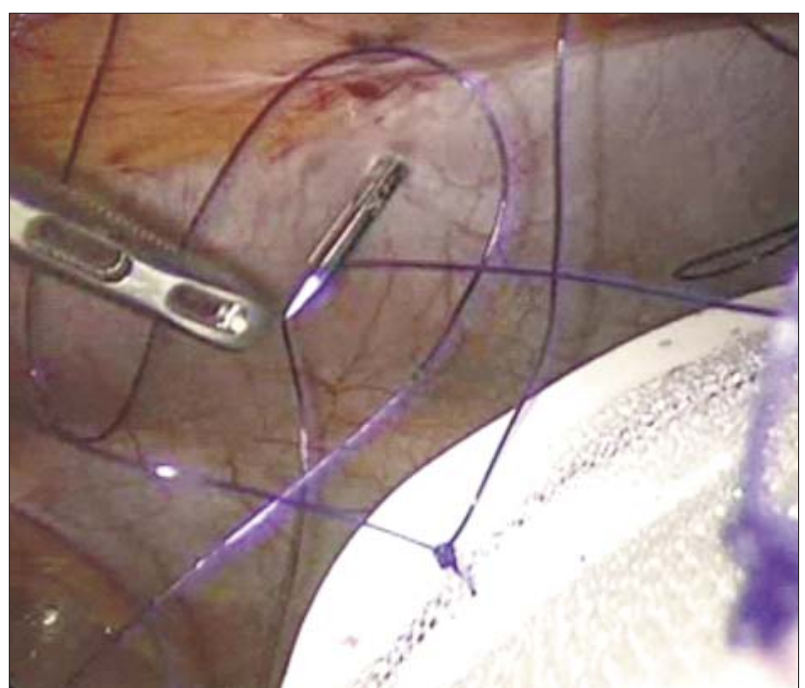

Figure 5. Mesh fixed to abdominal wall

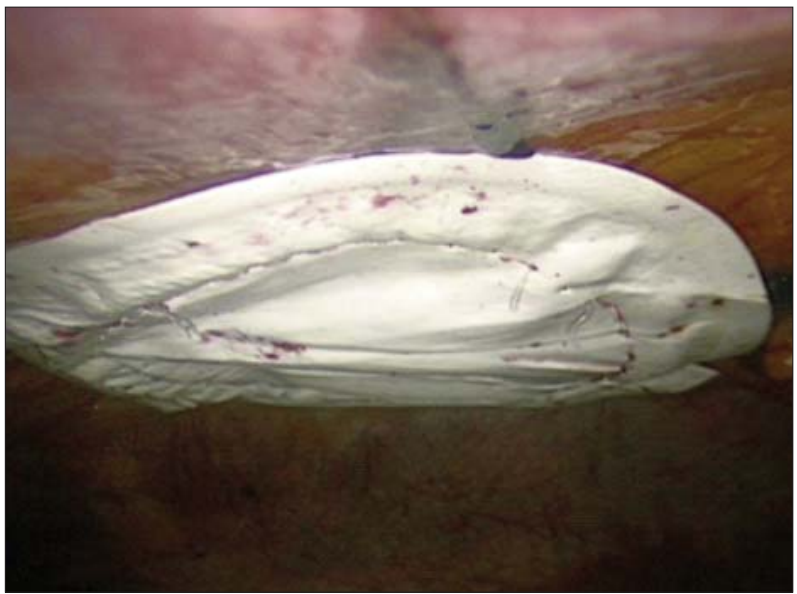

Figure 6. Final aspect

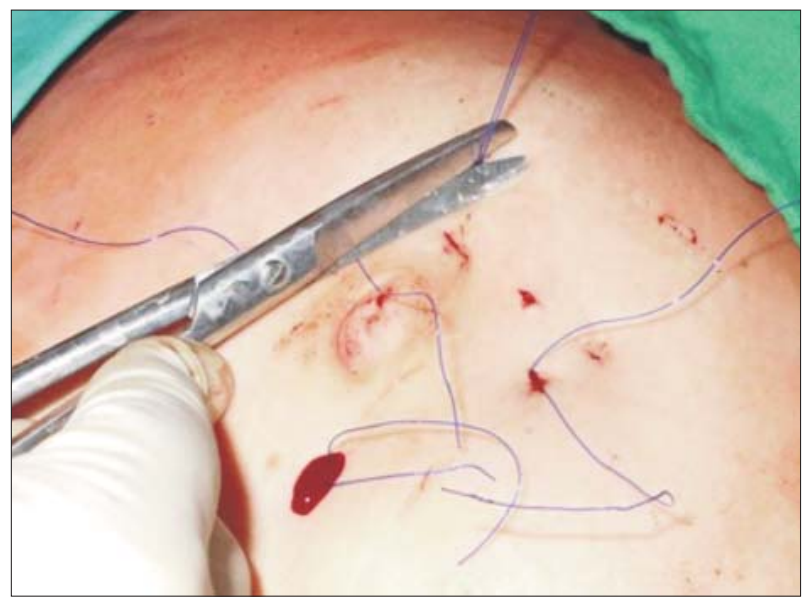

Figure 7. Stitches cut at skin level 
after 12-24 hours and the patient may be discharged after 24-48 hours. Thromboembolism prophylaxisis done selective on patients with risk. Compressive bandage on the defect is changed but it is maintained for 7-10 days for the prophylaxis of parietal seroma.

\section{Results}

Between November 2014 - November 2018, 28 patients with small $\mathrm{VH}$ have undergone laparoscopic surgery, using the Ventralex ${ }^{\mathrm{TM}}$ Hernia Patch, with the diameter of $8 \mathrm{~cm} .16$ women and 12 men patients, with an average age of 53,3 years (29-72 years). Interventions included $22 \mathrm{UH}, 2 \mathrm{EH}$, one Spiegel left side hernia, one incisional hernia after an open surgery of an UH with a Ventralex mesh of $6,4 \mathrm{~cm}$ and 2 ET after a laparoscopic colecystectomy. Repair of the parietal defect for $\mathrm{UH}$ and $\mathrm{EH}$ has not been performed for the first 4 patients.

5 patients were obese and 13 over-weight, one patient was a trained athlete, 7 patients have requested laparoscopic surgery. 12 patients had secondary illnesses: 9 had high blood pressure (one patient with $\mathrm{BRD}$, another with CID), one with BPOC, 3 with type II diabetes, and one patient with Hepatitis B.

The mean operating time was 52 minutes (42-66 minutes) and the postoperative hospital stay was of 1,8 days (1-5 days). There was only one complication, prolonged postoperative pain (over 14 days). There were no recurrences. The patient with an incisional hernia presented a defect unfolding of the mesh inserted on open surgery (Fig. 8).

\section{Discussion}

Surgical treatment of VH is represented by the simple suture and the mesh suture for open surgery and the laparoscopic repair with mesh. At the moment, there is no unanimous opinion regarding the elected surgery for small $\mathrm{VH}$, but regarding PVH, most of them are umbilical and epigastric, in about $90 \%$ of them the parietal defect does not exceed 2 centimeters (11). There is still a lot of controversy, hence the multiple

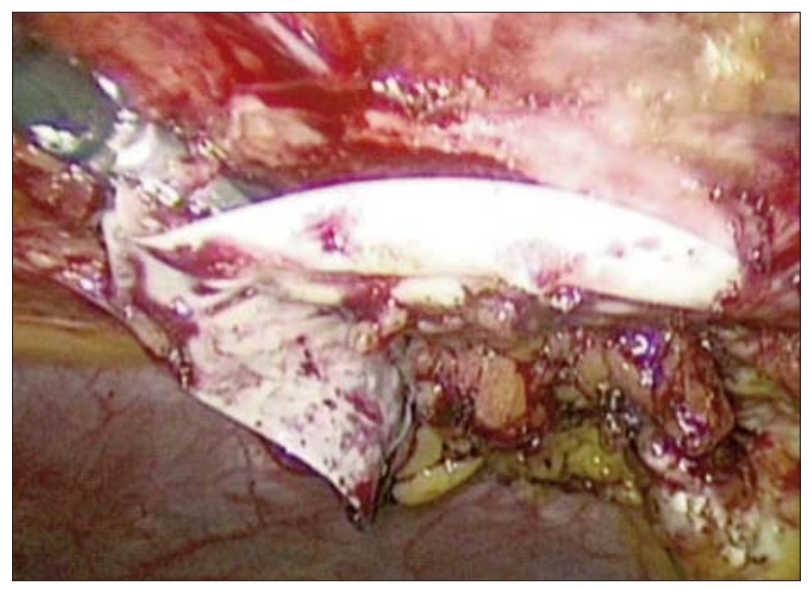

Figure 8. Poor mesh deployment

surgery techniques, with mesh or without, placement of the mesh according to the sheath of the abdominal wall, classic or robotic laparoscopy, what mesh to use, how to fixate it, transfacial suture or with tacks, metal or plastic tacks, absorbable or non-absorbable, fixation with surgical glue, closing or not the parietal defect, and so on. Simple suture is widely used, as it is accessible and cost effective, recommended for PVH patients with no risk factors.

Thus the question arises whether the mesh is indicated in $\mathrm{VH}$ and if laparoscopyis not too much. Due to the increased incidence of recurrences, nowadays authors and guides recommend mesh suture and laparoscopy for patients with risks, including for small VH $(4,5,11,12)$. The usage of mesh slightly reduces recurrences. In a meta-analysis regarding suture versus mesh suture in small VH, the incidence of recurrences has been of $8,2-14,7 \%$ and $1-3,3 \%$, seroma $0-6 \%$ and $4,8-6 \%$ (13). In a recent $\mathrm{RCT}$ (300 patients), the recurrences after repair of small and middle-sized UH (1-4 $\mathrm{cm}$ ) were $3,6 \%$ in the mesh group versus $11,4 \%$ in the suture group (14). Main risk factors in VH recurrence are obesity, diabetes, smoking, ascites, immunosuppression, primary suture, local infection $(7,15)$.

Laparoscopy reduces incidence of parietal infections, as well as hospital stay and postoperative recovery in $\mathrm{VH}(16,17)$. In a metaanalysis regarding parietal infections in $\mathrm{PVH}$, 
their incidence has been $2,3 \%$ in laparoscopy and $9,2 \%$ in open surgery, and in incisional hernias $1,6 \%$ and $10,1 \%$, with non-differentiated statistical recurrence of $3,6 \%$ versus $4,3 \%$, and $8,5 \%$ versus $10,1 \%$ (16).

In case of ET, these have an incidence of 0 $5,2 \%$, over $65 \%$ are para-umbilical and can be considered UH, they are more frequent after fundoplication and gynecological surgery, risk factors are trocar pyramid tip, $12 \mathrm{~mm}$ trocars, single port operations, enlargement of incision, obesity, age, operating time (18-20). Suture of parietal defect is optional. The benefit is the reduction of the defect dimensions and inclusively of the mesh, for the incidence of parietal seroma and, except for the first 4 patients, it was the surgery of choice (21). The main mechanisms involved in recurrences are infections, careless placement of mesh, smaller size of the mesh and inadequate coverage of the defect (excess of $3-5 \mathrm{~cm}$ compared to the defect), increase of intra-abdominal pressure. For small parietal defects, the margins of the mesh must exceed the margins of the defect by a minimum $3 \mathrm{~cm}$, and the Ventralex ${ }^{\mathrm{TM}}$ mesh ensures this for small $\mathrm{VH}(4,5,12,22)$.

Our team faces two major issues. On the one side, there is scientific evidence, and on the other side, there is cost. So, simple suture is the most cost-effective, but it is associated with an important number of recurrences, and the repair of these recurrences is more expensive than laparoscopic surgery, which offers the best quality of post-operative life. Moreover, although laparoscopy is more expensive than open surgery, the reduction of hospital stay and recovery, of post-operative complications and reinterventions make it more cost-effective (17,23).

The Ventralex ${ }^{\mathrm{TM}}$ mesh has been created for intra-peritoneal placement in open surgery, and it has the same characteristics as special meshes for laparoscopy. The advantage of this mesh is that it is more cost-effective compared to other products, it is circular preformed so as to efficiently cover defects of maximum 2 centimeters, and it can be simply fixated with 4 transfacial sutures. In the medical literature, contraction of ePTFE meshes is in average of $7,5 \%$ and $6,7 \%$, and $28 \%$, respectively $27,5 \%$ of the patients did not present shrinkage $(24,25)$. In the published series, recurrence after intraperitoneal placement of the Ventralex ${ }^{\mathrm{TM}}$ mesh in open surgery for small VH has been $2,6 \%$ $14,8 \%$, and the meshes used had between 6,4 and $8 \mathrm{~cm}$ in diameter (26-29). At the 25-month laparoscopic check-up, for patients with open intra-peritoneal surgery with Ventralex ${ }^{\mathrm{TM}}$ mesh, in a series, recurrence was $14,8 \%$, and the main causes were identified to be incomplete digital lysis of adhesions, fatty or omental adhesions against the abdominal wall or the fatty umbilical ligament prominent and too close to the hernia area to allow flat patch placement, and also a deficiency of the unfolding ring, which lead to an inadequate deployment and the deformation of the mesh, "cupping" or "potato-chip formation" in almost $80 \%$ of patients, which favors recurrences (27). The recurrence of our patient may be associated to an unfolding defect, as well as to the dimensions of the mesh, $6,4 \mathrm{~cm}$. In laparoscopy, the unfolding and flattening of the mesh are directly visualized and may be corrected.

\section{Conclusion}

In conclusion, we consider that the $8 \mathrm{~cm}$ "Ventralex ${ }^{\mathrm{TM}}$ Hernia Patch" is a viable option for laparoscopic repair of small VH, it is circular preformed, perfectly overlaps defects of maximum $2 \mathrm{~cm}$, it is easily fixated with 4 trans- $^{-}$ facial sutures, optimal unfolding may be verified in laparoscopy, and it is cost-effective. Our technique is minimally invasive, it is safe and easy to reproduce and it especially addressees patients with recurrence risk factors.

\section{Conflict of interest: none}

\section{Financial support and sponsorship: none}

\section{References}

1. Pham CT, Perera CL, Watkin DS, Maddern GJ. Laparoscopic ventral hernia repair: a systematic review.Surg Endosc. 2009;23:4-15 
2. Muysoms F E., Miserez M., Berrevoet F. Campanelli, G. G. Champault, E. Chelala, et al. Classification of primary and incisional abdominal wall hernias. Hernia. 2009; 13:407-414

3. Earle DB, McLellan JA.Repair of umbilical and epigastric hernias.Surg Clin North Am. 2013;93:1057-89

4. Christoffersen MW, Helgstrand F, Rosenberg J, Kehlet $\mathrm{H}$, Bisgaard T. Lower reoperation rate for recurrence after mesh versus sutured elective repair in small umbilical and epigastric hernias. A nationwide register study.World J Surg. 2013;37(11):2548- 52

5. Berrevoet F, Doerhoff C, Muysoms F, et al.A multicenter prospective study of patients undergoing open ventral hernia repair with intraperitoneal positioning using the monofilament polyester composite ventral patch: interim results of the PANACEA study.Med Devices. 2017;12(10):81-88.

6. Christoffersen MW.Clinical outcomes after elective repair for small umbilical and epigastric hernias.Dan Med J. 2015;62(11):B5161.

7. Bittner R, Bingener-Casey J, Dietz U et al.Guidelines for laparoscopic treatment of ventral and incisional abdominal wall hernias (International Endohernia Society [IEHS])—Part 2.Surg Endosc. 2014;28:353-79.

8. Froylich D, Segal M, Weinstein A, Hatib K, Shiloni E, Hazzan D. Laparoscopic versus open ventral hernia repair in obese patients: a long-term follow-up.Surg Endosc. 2016 Feb;30(2):670-5

9. [https://www.davol.com/ordering-info/sp/ventralex-hernia-patch]

10. Nicolau AE. [Laparoscopic repair of abdominal ventral hernias.Chirurgia (Bucur). 2010;105(6):817-22

11. Helgstrand F.National results after ventral hernia repair.Dan Med J 2016;63(7). pii: B5258

12. Earle D, Roth JS, Saber A, et al. SAGES guidelines for laparoscopic ventral hernia repair.Surg Endosc. 2016;30(8):3163-83)

13. Nguyen MT, Berger RL, Hicks SC, et al. Comparison of outcomes of synthetic mesh vs suture repair of elective primary ventral herniorrhaphy: a systematic review and meta-analysis. JAMA Surg. 2014;149(5):415-21

14. Christoffersen MW, Helgstrand F, Rosenberg J, et al.Long-term recurrence and chronic pain after repair for small umbilical or epigastric hernias: a regional cohort study.Am J Surg. 2015;209(4):725-32

15. Shankar DA, Itani KMF, O'Brien WJ, Sanchez VM.Factors Associated With Long-term Outcomes of Umbilical Hernia Repair.JAMA Surg. 2017 May 1;152(5):461-466.

16. Arita NA, Nguyen MT, Nguyen DH, Berger RL, Lew DF, Suliburk JT, et al.Laparoscopic repair reduces incidence of surgical site infections for all ventral hernias.Surg Endosc. 2015;29(7):1769-80

17. Ecker BL, Kuo LE, Simmons KD, Fischer JP, Morris JB, Kelz RR et al. Laparoscopic versus open ventral hernia repair: Iongitudinal outcomes and cost analysis using statewide claims data.Surg Endosc. 2016 ;30:906-15.
18. Swank HA, Mulder IM, la Chapelle CF, Reitsma JB, Lange JF, Bemelman WA. Systematic review of trocar-site hernia.Br J Surg. $2012 ; 99(3): 315-23$

19. Helgstrand F, Rosenberg J, Kehlet $\mathrm{H}$, Bisgaard T Low risk of trocar site hernia repair 12 years after primary laparoscopic surgery.Surg Endosc. 2011;25(11):3678-82

20. Antoniou SA, Morales-Conde S, Antoniou GA,Granderath FA, Berrevoet F, Muysoms FE; Bonham Group. Single-incision laparoscopic surgery through the umbilicus is associated with a higher incidence of trocar-site hernia than conventional laparoscopy: a meta-analysis of randomized controlled trials. Hernia. 2016;20(1):1-10

21. Nguyen DH, Nguyen MT, Askenasy EP, Kao LS, Liang MK.Primary fascial closure with laparoscopic ventral hernia repair: systematic review.World J Surg. 2014 Dec;38(12):3097-104.

22. Silecchia G, Campanile FC, Sanchez L, Ceccarelli G, Antinori A, Ansaloni L,et al.Laparoscopic ventral/incisional hernia repair: updated Consensus Development Conference based guidelines [corrected].Surg Endosc. 2015 Sep;29(9):2463-84

23. Colavita PD, Tsirline VB, Walters AL, Lincourt AE, Belyansky I, Heniford BT Prospective, long-term comparison of quality of life in laparoscopic versus open ventral hernia repair.Ann Surg. 2012;256(5):714-22

24. Schoenmaeckers EJ, van der Valk SB, van den Hout HW, Raymakers JF, Rakic S.Computed tomographic measurements of mesh shrinkage after laparoscopic ventral incisional hernia repair with an expanded polytetrafluoroethylene mesh. Surg Endosc. $2009 ; 23(7): 1620-3$

25. Carter PR1, LeBlanc KA, Hausmann MG, Whitaker JM, Rhynes VK, Kleinpeter KP, et al. Does expanded polytetrafluoroethylene mesh really shrink after laparoscopic ventral hernia repair? (abstr.)Hernia. 2012;16(3):321-5

26. Iversen E, Lykke A, Hensler M, Jorgensen LN.Abdominal wall hernia repair with a composite ePTFE/polypropylene mesh: clinical outcome and quality of life in 152 patients.Hernia. 2010 Dec;14(6):555-60.

27. Berrevoet F, Van den Bossche B, de Baerdemaeker L, de Hemptinne B.Laparoscopic evaluation shows deficiencies in memory ring deployment during small ventral hernia repair.World J Surg. 2010;34(7):1710-5

28. Tollens T, Den Hondt M, Devroe K, et al. Retrospective analysis of umbilical, epigastric, and small incisional hernia repair using the Ventralex ${ }^{\mathrm{TM}}$ hernia patch. Hernia. 2011:15(5):531-40

29. Bensaadi H, Paolino L, Valenti A, Polliand C, Barrat C, Champault G.Intraperitoneal tension-free repair of a small midline ventral abdominal wall hernia: randomized study with a mean follow-up of 3 years.Am Surg. 2014;80(1):57-65 